\title{
Long-term outcome in Felty's syndrome
}

\author{
CARTER THORNE AND MURRAYB. UROWITZ \\ From the Rheumatic Disease Unit, University of Toronto, Wellesley Hospital, Toronto, Canada
}

SUMMARY Felty's syndrome has again been shown to be a severe form of systemic rheumatoid disease characterised by severe joint involvement, many extra-articular features, and a high incidence of infection. In addition we have shown that splenectomy was not protective for infections and in fact may on occasion contributed to infection. Furthermore, although most patients had an increase in white blood cell count after splenectomy, $50 \%$ of patients without splenectomy showed a similar increase in white blood cell counts at follow-up. Mortality in Felty's syndrome was high, with infection being the main cause of death.

The clinical triad of rheumatoid arthritis, leucopenia, and splenomegaly, first described by Felty in $1924,{ }^{1}$ is now generally regarded as a unique variant of rheumatoid disease characterised by a prominence of extra-articular features as well as severe, destructive joint disease. ${ }^{2} \mathrm{~A}$ number of reviews have given a retrospective analysis of the clinical course of Felty's syndrome. ${ }^{3-6}$ We report a prospective analysis of 25 patients previously described with regard to disease activity including articular changes, extra-articular features, and laboratory variables and outcome in terms of infection and death.

\section{Material and methods}

Thirty-four patients with Felty's syndrome formed an original study group evaluated at the Wellesley Hospital. ${ }^{2}$ These original patients fulfilled the following criteria for Felty's syndrome: (1) classical or definite rheumatoid arthritis (ARA criteria); (2) splenomegaly; (3) leucopenia of less than $4 \times 10^{9} / 1$ or neutropenia of less than $2 \times 10^{9} / 1$, or thrombocytopenia of less than $100 \times 10^{9 / 1}$; (4) no other causes for cytopenia or splenomegaly.

Of the original 34 patients evaluated 16 were alive and available for recall on a prospective basis. Nine patients had died in the follow-up period, and their charts were reviewed. Five of the patients were lost to follow-up and not evaluated. Four patients were dead at the time of the first evaluation. Thus 25 patients could be evaluated according to a predesigned protocol. ${ }^{2}$ The level of joint inflammatory activity was estimated according to the articular index method of Lansbury $^{7}$ and by a count of inflamed joints. $X$-rays

Accepted for publication 7 October 1981.

Correspondence to Dr M. B. Urowitz, Wellesley Hospital, 160 Wellesley Street East, Room 649 N, Toronto, Canada M4Y 1 J3. of the hands and feet were evaluated according to the method of Kellgren et al. ${ }^{8}$ and those with stage III and IV were tabulated. Criteria for extra-articular features were based on those previously described. ${ }^{29}$

Serological tests included latex fixation for rheumatoid factor, fluorescent antinuclear antibody test, total haemolytic complement, C3, protein electrophoresis, and DNA binding by the Farr technique. Additional laboratory investigations for abnormalities of liver function tests were performed and will be reported in a separate communication.

\section{Results}

CLINICAL EVALUATION

The 25 patients consisted of 8 males and 17 females. The age at follow-up was $62 \cdot 5$ years (range 48 to 77 years). The follow-up period from the original assessment was a mean of 5 years (1-12 years). The disease duration at the time of this study for rheumatoid arthritis was a mean of 23.5 years with a range of 8-30 years, and for Felty's syndrome was $7 \cdot 5$ years with a range of 1-14 years. At the time of reassessment in 21 patients able to be evaluated 12 had shown an improvement in joint count, that is, a greater than $50 \%$ reduction in articular index or active joint count (Table 1). Of these, 11 had fewer than 5 active joints. Of the remaining 9 patients 7 continued to have essentially the same number of active joints or the same articular index, and 2 patients had more active peripheral arthritis. Comparable sets of $x$-rays were available in 8 patients. There was no significant change in joint damage or radiological stage from the initial assessment.

Extra-articular manifestations of rheumatoid disease were assessed in 20 patients (Table 2). During a mean of 5 years of follow-up there was an average 
Table 1 Felty's syndrome: long-term follow-up (25 patients)

\begin{tabular}{lll}
\hline & $\begin{array}{l}\text { Initial assessment } \\
4 \cdot 7 \text { yr post } \\
\text { diagnosis FS }\end{array}$ & $\begin{array}{l}\text { Present assessment } \\
9 \cdot 7 \text { yrs post } \\
\text { diagnosis FS }\end{array}$ \\
\hline Articular index & 65 & 34 \\
Joint count & 13.9 & $7 \cdot 7$ \\
Latex titre $^{*}$ & 5.9 & 5.5 \\
\hline
\end{tabular}

*Tube dilution, 1:40=1. FS=Felty's syndrome.

Table 2 Felty's syndrome: long-term follow-up (25 patients)

\begin{tabular}{lll}
\hline & $\begin{array}{l}\text { Initial assessment } \\
4 \cdot 7 \text { yr post } \\
\text { diagnosis FS }\end{array}$ & $\begin{array}{l}\text { Present assessment } \\
9 \cdot 7 \text { yr post } \\
\text { diagnosis FS }\end{array}$ \\
\hline Nodules & 55 & 75 \\
Lymphadenopathy & 20 & 5 \\
Hepatomegaly & 10 & 15 \\
Leg ulcers & 25 & 25 \\
Peripheral neuropathy & 5 & 3 \\
Sjögren's syndrome & 35 & 50 \\
Episcleritis & 0 & 10 \\
Pericarditis & 0 & 0 \\
Pleuritis & 0 & 0 \\
Pulmonary fibrosis & 15 & 15 \\
Vasculitis & 25 & 35 \\
Raynaud's disease & 10 & 15 \\
Thrombophlebitis & 0 & 10 \\
Thyroid abnormality & 5 & 15 \\
Myopathy & 0 & 5 \\
Mean per patient & $1 \cdot 7$ & $2 \cdot 4$ \\
\hline
\end{tabular}

FS= Felty's syndrome.

increase of 0.7 articular feature. It is to be noted that, in some cases, previous extra-articular features had resolved, for example, leg ulcers, lymphadenopathy, hepatomegaly, etc. Spleen size had become normal in 6 patients, and in each of these the white cell count was greater than $4 \times 10^{9} / 1$. Two patients with normal white cell counts still had palpable spleens.

Sepsis. There was a history of infection in 15 of the 25 patients. These comprised bronchopulmonary infections, severe skin infections, and pyoarthrosis with Gram-positive or Gram-negative organisms. The nature of the infections and the organisms involved were similar for patients with and without splenectomies. Five of 9 deaths were related to sepsis. Seven patients had had splenectomies for infection and 5 continued to have infection despite a normal white cell count. Three of the patients who had had splenectomies for infection died of infection, one in the immediate postsplenectomy period. Six patients without splenectomy developed recurrent infection during follow-up. In 2 the white cell count was normal, and in 4 it was less than $4(2 \cdot 4-3 \cdot 9) \times$ $10^{9} / 1$.

Splenectomy. Eleven patients in this group underwent splenectomy (Table 3). However, in the follow-up period since the original assessment only 2 other patients have undergone splenectomies, one for infection and one for portal hypertension. In the whole group infections remained the major indication for splenectomy, followed by severe leucopenia or persistent skin ulceration. As noted in Table 3, infection continued to be a significant problem after splenectomy in a large number of patients. Of 10 patients who had follow-up white cell counts after splenectomy 9 had counts of greater than $5 \times 10^{9} / 1$ at this assessment (mean $9 \cdot 2$, range $4 \cdot 8-16 \cdot 7$ ). Their mean granulocyte count was 4.6 (range $1-9.5) \times$ $10^{9} / 1$.

Deaths. There were 9 deaths in the follow-up period. Sepsis was the primary or contributing factor in 5 of the patients. One patient died of cancer of the bowel, 2 died with severe, upper gastrointestinal bleeding, and 2 had a sudden death. The patients who died had a mean age of 65 (range 55 to 77 years), as compared with the living patients, who had a mean age of 60 (range 48 to 77 years). However, other clinical variables did not suggest a more severe disease in those patients who died. The disease duration of rheumatoid arthritis and Felty's syndrome was slightly longer in the living patients, and the mean number of extra-articular features was the same in both groups (Table 4).

LABORATORY EVALUATION

The erythrocyte sedimentation rate (ESR, Westergen) fell by $50 \%$ in 14 of 21 patients for whom it was available. The mean initial ESR was $76 \mathrm{~mm} / \mathrm{h}$ and at the present assessment was $20 \mathrm{~mm} / \mathrm{h}$. Of particular interest is the fact that the white cell count was

Table 3 Felty's syndrome: long-term outcome of splenectomy (11 patients)

\begin{tabular}{llll}
\hline Indications & No. & $\begin{array}{l}\text { Postsplenectomy } \\
\text { infection }\end{array}$ & $\begin{array}{l}\text { Septic } \\
\text { death }\end{array}$ \\
\hline Infection & 7 & 5 & 1 \\
Low WBC & 2 & 1 & 1 \\
Skin ulcers & 1 & 1 & 1 \\
Portal hypertension & 1 & - & - \\
\hline
\end{tabular}

WBC $=$ White blood cells.

Table 4 Felty's syndrome: long-term outcome-deaths $(9$ patients)

\begin{tabular}{lllll}
\hline & Age $(y r)$ & \multicolumn{2}{c}{ Disease duration } & EAF \\
\cline { 3 - 5 } & & RA $(y r)$ & $F S(y r)$ & \\
\hline Dead & $65(55-77)$ & $22 \cdot 5$ & $7 \cdot 4$ & $2 \cdot 8$ \\
Living & $60(48-77)$ & $24 \cdot 1$ & $8 \cdot 2$ & $2 \cdot 8$ \\
\hline
\end{tabular}

$\mathbf{R A}=$ rheumatoid arthritis. $\mathbf{F S}=$ Felty's syndrome. $\mathrm{EAF}=$ extra-articular features. 
greater than $4 \times 10^{9} / 1$ in 16 of 24 patients at the time of this assessment. This included 7 of 14 patients who had not had splenectomies and one patient who had received neither steroids nor a disease-suppressive drug. Of the remaining 6 patients in whom the white cell count had become normal 2 had taken steroids and gold, 2 had received only prednisolone, and 2 had received either chloroquine or gold. As noted previously, 9 of 10 patients who underwent splenectomy had white cell counts consistently greater than 5 $\times 10^{6} / 1$. However, at the initial assessment the mean white cell count was $4.2 \times 10^{9} / 1$ and at the present assessment the it is 4.9 . The latex titre showed no significant change in the follow-up period.

\section{Discussion}

The natural history of Felty's syndrome is uncertain with respect to joint disease, extra-articular and haematological features, susceptibility to infection, and mortality. The value of various types of therapy for specific complications of Felty's syndrome such as severe leucopenia, recurrent infections, or persistent leg ulcerations is not clear. ${ }^{10}$ Furthermore, there have been isolated reports of spontaneous haematological remissions in this syndrome..$^{41}$

This study reports a 10-year follow-up of 25 of an original 34 patients with Felty's syndrome reported on in 1977. At the initial assessment most of them had destructive arthritis but continued to have active joint disease. In the follow-up interval active joint disease decreased in the majority and joint damage had not progressed further. The mean number of extra-articular features had increased by 0.7 , again emphasising the systemic nature of this variant of rheumatoid disease.

The white blood cell count had increased to normal values in 16 of 24 patients including 7 of 14 who had not undergone splenectomy. This represented a persistent return to normal of the white cell count and a haematological remission. Other reports have suggested that an increase in white cell counts after splenectomy may be only transient..$^{2-5}$ However, 9 of 10 patients after splenectomy in this series had white cell counts in excess of $5 \times 10^{9} / 1$. It is of interest that 5 of these patients continued to have recurrent infections.

The mechanism of the leucopenia in Felty's syndrome remains controversial. Postulated mechanisms include humoral factors, ${ }^{12}{ }^{13}$ cell-mediated factors, ${ }^{14}{ }^{15}$ increased neutrophil margination, ${ }^{16}$ sequestration of cells in the spleen, ${ }^{17}{ }^{18}$ and phagocytosis of neutrophils by the spleen. ${ }^{19}$ Our finding of a large group of patients with coincident return to normal of spleen size and increase in neutrophil count supports the concept that the spleen may play a role in the pathogenesis of the neutropenia.

Infection persisted in patients with and without splenectomy and did not seem to be related to the presence of leucopenia, as in previous studies. ${ }^{34}$ This suggests the importance of an intrinsic defect of polymorph function (or other normal defence mechanisms) that is, diminished granulocyte reserves,${ }^{20}$ defective phagocytosis, ${ }^{17}$ chemotaxis, ${ }^{21}$ and killing. ${ }^{22}$

Splenectomy was performed for 4 different indications (Table 3). Although leucopenia, skin ulcers, and portal hypertension improved after splenectomy, infections recurred in a significant number of patients whether they had been the indication for the splenectomy or not. Furthermore this sepsis was the cause of death in some these patients. Thus splenectomy was not protective for sepsis in Felty's syndrome.

The 5-year mortality was high, 9 deaths among 25 patients (36\% 5-year mortality). This compares with a $20 \%$ mortality for patients admitted to hospital with rheumatoid arthritis assessed over a 5-year period. ${ }^{9}$ There were no differences in disease duration or number of extra-articular features in the dead or the living groups of patients, though the patients who died were an average of 5 years older. Infections remained the leading cause of death in this group (5 of 9 deaths).

\section{References}

${ }^{1}$ Felty A R. Chronic arthritis in the adult, associated with splenomegaly and leukopenia. Johns Hopkins Med J 1924; 395: 16-20.

2 Sienknecht C W, Urowitz M B, Pruzanski W, Stein H B. Felty's syndrome: clinical and serological analysis of 34 cases. $A n n$ Rheum Dis 1977; 36: 500-7.

3 Ruderman M, Miller L M, Pinals R S. Clinical serological observation on 27 patients with Felty's syndrome. Arthritis Rheum 1968; 118: 377-84.

4 Barnes C G, Turnbull A L, Vernon-Roberts B. Felty's syndrome: a clinical and pathological survey of 21 patients and their response to treatment. 'Ann Rheum Dis 1971; 30: 359-74.

5 Moore R A, Brunner C M, Sandusky W R, Leavell B S. Felty's syndrome: long-term follow-up after splenectomy. Ann Intern Med 1971; 75: 381-5.

6 Spivak J L. Felty's syndrome: an analytical review.Johns Hopkins Med J 1977; 141: 156-62.

7 Lansbury J. Methods for evaluating rheumatoid arthritis. In: Hollander J L, McCarty D J, eds. Arthritis and Allied Conditions. Philadelphia: 1972. Lea and Febiger,

${ }^{8}$ Kellgren J H, Jeffrey M R, Ball J. The epidemiology of chronic rheumatism. Atlas of Standard Radiographs of Arthritis. Oxford: Blackwell, 1963: 2.

- Gordon D A, Stein J L, Broder I. The extra-articular features of rheumatoid arthritis: a systemic analysis of 127 cases. Am J Med 1973; 54: 445-52.

10 Goldberg J, Pinals R S. Felty syndrome. Semin Arthritis Rheum 1980; 10: 52-65.

11 Luthra H S, Hunder G G. Spontaneous remission of Felty's syndrome. Arthritis Rheum 1975; 18: 515-7.

12 Logue G. Felty's syndrome: granulocyte-bound immunoglobulin $\mathrm{G}$ and splenectomy. Ann Intern Med 1976; 85: 437-42. 
13 Duckham D J, Rhyne R L, Smith F E, Williams R C. Retardation of colony growth of in-vitro bone marrow culture using sera from patients with Felty's syndrome, disseminated lupus erythematosus (SLE), rheumatoid arthritis and other disease states. Arthritis Rheum 1975; 18: 323-33.

14 Bagy G C, Gabourel J D. Neutropenia in three patients with rheumatic disorders: suppression of granulopoiesis by cortisol-sensitive thymus-dependent lymphocytes. J Clin Invest 1979; 64: 72-82.

${ }^{15}$ Slavin S, Liang $M \quad H$. Cell mediated autoimmune granulocytopenias in a case of Felty's syndrome. Ann Rheum Dis 1980; 39: 399-402.

16 Vincent P C, Levi J A, MacQueen A. The mechanism of neutropenia in Felty's syndrome. Br J Haematol 1974; 27: 463-75.

${ }^{17}$ Hurd E R, Andreis M, Ziff M. Phagocytosis of immune complexes by polymorphonuclear leukocytes in patients with Felty's syndrome. Clin Exp Immunol 1977; 28: 413-25.
${ }^{18}$ Wright C S, Doan C A, Bouroncle B A, Zillinger R M. Direct splenic arterial and venous blood studies in the hypersplenic syndromes before and after epinephrine. Blood 1951; 61: 195-212.

19 Bishop C R, Rothstein G, Ashenbracker H E, Athen J W. Leukokinetic studies X15. Blood neutrophil kinetics in chronic, steady state neutropenia. J Clin Invest 1971; 50: 1678-89.

w Kindall H R, Wolff S M, Talal N, Plotz P H, Decker J L. Marrow franulocyte reserves in the rheumatic diseases. Arthritis Rheum 1973; 16: 345-52.

${ }^{21}$ Zivkovic M, Baum J. Chemotaxis of polymorphonuclear leukocytes from patients with systemic lupus erythematosus and Felty's syndrome. Immunol Commun 1972; 1: 39-49.

${ }^{22}$ Gupta R C, Laforce F M, Millo D M. Polymorphonuclear leukocyte inclusions and impaired bacterial killing in patients with Felty's syndrome.J Lab Clin Med 1976; 88: 183-93. 